\title{
Collective Action, Violence, and Clientelism during Argentina's 2001 Crisis
}

\author{
Fernanda Page Poma ${ }^{1}$
}

In a context of an economic, social, and political crisis that resulted in widespread food riots and uprisings, what explains the absence of collective violence and lootings in a district with a legacy of intense mobilization? I argue that the answer to this question lies in a specific combination of patronage politics and collective action. Far from dominating their clients and preventing horizontal ties, brokers in the poverty-stricken district of Florencio Varela in Argentina mobilized the population to act together and suppress violence. Drawing on indepth interviews, newspaper reports, and secondary sources, I posit that during the peak of the revolts in December of 2001, brokers in this district appeared to validate collective mobilization seeking to prevent violence and lootings. The primary significance of this work is the differential way in which patron-client ties unfold to promote participation and collective actions. [Article copies available for a fee from The Transformative Studies Institute. E-mail address: journal@transformativestudies.org Website: http://www.transformativestudies.org (O2020 by The Transformative Studies Institute. All rights reserved.]

KEYWORDS: Collective Action, Patronage Politics, Lootings, Argentina.

\section{INTRODUCTION}

In December of 2001, Argentina was undergoing an economic, social, and financial crisis that led to an explosion of mass protests and riots and the resignation of the president. Thousands of poor and unemployed

\footnotetext{
${ }^{1}$ Fernanda Page Poma holds an M.A. and Ph.D. both in Sociology from the State University of New York (SUNY) at Stony Brook. She also holds a Licenciatura in Political Science from the University of Buenos Aires (UBA) and a Postgraduate Diploma in Education from the University of San Andrés. Fernanda was Fulbright Scholar, and received fellowships from DSD-SSRC, Tinker Foundation and SUNY Stony Brook. Currently, she is Postdoctorate Fellow and professor at the Department of Government and Politics, Universidad Nacional de San Martín, Argentina. Address correspondence to: Fernanda Page Poma, e-mail: fernandapage@gmail.com.
} 